\title{
Ecological distribution of stream macroalgae in different spatial scales using taxonomic and morphological groups
}

\author{
ROGÉRIO ANTONIO KRUPEK ${ }^{1,3}$ and CIRO CESAR ZANINI BRANCO²
}

(received: October 02, 2011; accepted: August 09, 2012)

\begin{abstract}
Ecological distribution of stream macroalgae in different spatial scales using taxonomic and morphological groups). We examined the ecological distribution of macroalgal communities in streams using species groups (taxonomic units = algal phyla, and morphological $=$ morphological types) with similar structures and functions instead of the species themselves. The study was conducted from June to July/2007 in two drainage basins located in mid-southern region of Paraná State, Brazil. Evaluations of macroalgal communities took into consideration the following spatial scales: the drainage basin (the Pedras river and Marrecas river basins), shading regime (open and shaded stream segments), mesohabitats (riffles and pools), and microhabitats (sampling units of $0.05 \mathrm{~m}^{2}$ ). A total of 29 taxa (23 subgeneric, one generic, and five vegetative groups) were identified. On these, 12 taxa belong to Chlorophyta, 11 to Cyanobacteria, four to Heterokontophyta, and two to Rhodophyta. The proportions of morphological types were: $24 \%$ free filaments, $17.25 \%$ mats, tufts, gelatinous colonies, and gelatinous filaments, $7 \%$ crusts. In terms of spatial scales, we observed a predominance of Chlorophyta in open stream segments and Cyanobacteria in shaded stream segments, reflecting the loss of competitive advantage of green algae in sites with low energy availability. In the mesohabitats, the morphological types recorded in pools were predominantly poorly adapted to fast currents (free filaments), while those found in riffles (mats, tufts and gelatinous filaments) were highly resistant to fast water flows. As such, the use of species groupings based on algal taxonomy associated with morphological characteristics proved to be useful to understanding the distributions of these organisms in lotic environments.
\end{abstract}

Key words - distribution, functional group, macroalgae, stream

\section{INTRODUCTION}

Investigations of the spatial organization of aquatic communities in lotic environments, especially considering algae with clearly visible macroscopic growth (macroalgae "sensu" Sheath \& Cole 1992), have revealed interesting patterns that have generally been described as mosaics in which correlations between richness and species abundance are essentially obligatory (Borges \& Necchi Júnior 2006).

One pattern that appears to be universal among communities of lotic macroalgae (Hu \& Xie 2006, Krupek et al. 2007, Branco et al. 2009) is the restricted occurrence of most of the species to a single sampling segment within a larger sampling area (e.g. Branco et al. 2009). This spatial structuring has been attributed to specific characteristics of each river segment that result in distinct communities throughout lotic ecosystems (Krupek et al. 2007, Branco et al. 2009) - although it has been difficult to identify specific patterns and environmental variables explaining these distributions.

1. Universidade Estadual do Paraná, Departamento de Biologia, Campus de União da Vitória, Praça Cel. Amazonas s/n, Caixa Postal 291, 84600-000 União da Vitória, PR, Brazil.

2. Universidade Estadual Paulista, Departamento de Ciências Biológicas, Av. Dom Antônio, 2100, 19806-900 Assis, SP, Brazil.

3. Corresponding author: rogeriokrupek@yahoo.com.br
As such, the present study examined macroalgal communities with similar structures and functions and different algal phyla and morphological types to better understand their distribution patterns within different lotic environments.

\section{MATERIAL AND METHODS}

The present study was carried out in the drainage basins of the Pedras and Marrecas rivers, located in the municipality of Guarapuava in the central southern region of Paraná State, Brazil (figure 1). The hydrographic basin of the Pedras river $\left(25^{\circ} 13^{\prime}-25^{\circ} 26^{\prime} \mathrm{S}\right.$ and $\left.51^{\circ} 13^{\prime}-51^{\circ} 28^{\prime} \mathrm{W}\right)$ covers approximately $330 \mathrm{~km}^{2}$, while that of the Marrecas river $\left(25^{\circ} 54^{\prime}-26^{\circ} 21^{\prime} \mathrm{S}\right.$ and $52^{\circ} 54^{\prime}-53^{\circ} 17^{\prime} \mathrm{W}$ ) covers approximately $765 \mathrm{~km}^{2}$.

Analyses of the stream macroalgal communities were undertaken at the following spatial scales: 1 . Regional drainage basin, and; 2 . Local - a) mesohabitat $=$ pools with current velocities between 0 and $11.8 \mathrm{~cm} \mathrm{~s}^{-1}$, and riffles with current velocities greater than $\left.19.4 \mathrm{~cm} \mathrm{~s}^{-1} ; \mathrm{b}\right)$ microhabitat $($ sampling unit $)=$ predefined areas $(20 \mathrm{~cm}$ diameter circles $=$ $0.05 \mathrm{~m}^{2}$ ) in which all of the biotic variables (species richness and abundance) and environmental variables (luminousity, current velocity, depth, and substrate type) were evaluated. We also investigated the effects of the degree of shading by examining shaded stream segments (with well-developed vegetation along their banks) and open non-shaded stream segments (without significant stream-side vegetation) within each drainage basin. 


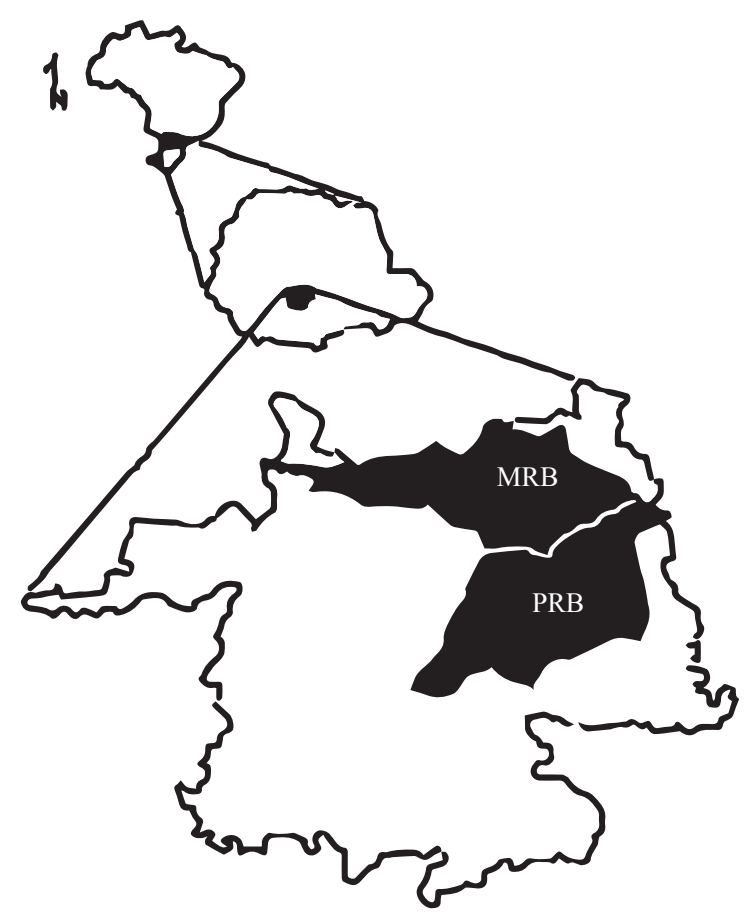

Figure 1. Schematic map of the Pedras river (PRB) and Marrecas river (MRB) drainage basins in Guarapuava Municipality in the central-southern region of Paraná State, Brazil.

The macroalgal communities and the environmental variables were evaluated between June and July/2007 in 20 streams, including 10 streams ( 5 open and 5 shaded) in the Pedras river basin, and 10 streams ( 5 open and 5 shaded) in the Marrecas river basin. Two types of mesohabitats were also analyzed in each stream: pools and riffles. Microhabitats within each mesohabitat were likewise analyzed, with each sampling site consisting of a stream segment between 10 and 20 metros long that was surveyed using the quadrate technique (Krebs 1989, Necchi Júnior et al. 1995).

The presence/absence of each macroalgae species was noted in each sampling unit, as well as its morphological type; its abundance was estimated visually in terms of percentage cover. Observations of community richness and abundance in each sampling unit were made with the aid of a sub-aquatic view-box device, and specimens representative of each species were collected and preserved for subsequent laboratory analyses.

The sampling units were installed in locations with evident macroalgae growth, whether in both riffle and pools mesohabitats. Twenty sampling units were established in each stream, whenever possible (10 in each mesohabitat).

The current velocity and irradiance levels were measured as close to the stream bottom as possible in each sampling unit using a Swoffer 2100 digital current meter and a Li-Cor 189 digital light meter (equipped with a Li-193SA spherical quantum sensor) respectively (Necchi Júnior 1997; Branco \& Necchi Júnior 1998). Water depth was likewise measured in each sampling unit, taken as the distance between the approximate center of the sampling quadrant and the water surface. The stream bottom substrate was classified based on the size particle classes proposed by Gordon et al. (1992). Two metric measures were used to quantify substrate heterogeneity: i. richness of substrate types, and ii. substrate diversity (obtained using the Shannon-Wiener diversity index of the numbers of different types of substrates and their respective percentage covers).

The following environmental variables were measured at each sampling site to characterize the general nature of each environment: water temperature, turbidity, specific conductivity, $\mathrm{pH}$, and dissolved oxygen. All of these variables were measured in the field using a Horiba U-10 water-quality meter equipped with a multi-parameter probe.

Preserved algal specimens harvested in the streams were transported to the laboratory where they were examined using a Carl Zeiss Jenamed 2 binocular microscope fitted with an ocular micrometer. The macroalgae were identified to the species (or infra-species) level whenever possible. The species classifications follow the system described by Van Den Hoek et al. (1995), except for the Cyanobacteria, which were classified according to Komárek \& Anagnostidis (1986, 1989) and Anagnostidis \& Komárek (1988).

All of the species encountered during the present study were classified into morphological types (mats, free filaments, gelatinous filaments, gelatinous colonial, crusts, and tufts) and according to their different algal phyla (Cyanobacteria, Chlorophyta, Rhodophyta, and Heterokontophyta). These groups were considered to be the functional types of the macroalgae communities.

The compositions of the macroalgae communities were analyzed using Detrended Correspondence Analysis (DCA), a multivariate ordination technique that orders sampling segments showing similar taxonomic compositions and summarizes the information along three axes (variables) (Ludwig \& Reynolds 1988). The DCA results are presented graphically here to detect groups of sampling sites at different spatial scales. These analyses were undertaken considering three distinct set of data: i) all of the species; ii) the different morphological types; and, iii) the algal phyla. Analyses were performed separately for each of the spatial scales considered (drainage basin, shading regime, and mesohabitat). The sampling point Pt01 (Pedras river, shaded, pools) was excluded from these analyses as no macroalgal species were encountered there.

Multiple Regression Analysis was subsequently applied to evaluate the relationships between groups of abiotic parameters (general and micro-environmental) and the biological variables (functional groups) at the different observation scales. All variables were first submitted to correlation analysis using the Pearson $r$ coefficient to establish whether they demonstrated co-variance or collinearity. Significant correlations were observed between the micro-environmental variables irradiation and depth $(r=-0.421 ; P<0.01)$ and between richness and substrate $\mathrm{H}^{\prime}$ 
$(r=0.716 ; P<0.001)$. Significant correlations were found among the general variables in terms of temperature and oxygen saturation $(r=-0.577 ; P<0.01)$, temperature and $\mathrm{pH}(r=0.569, P<0.01)$, and $\mathrm{pH}$ and oxygen saturation $(r=-0.610 ; P<0.01)$. All of the statistical analyses were performed using the Statistica 5.0 (Statisoft Incorporation) and PCORD 4.0 statistical software packages.

\section{RESULTS}

All environmental variables (general and microhabitat) at the different sampling scales are presented in table 1 .
A total of 29 taxa of macroalgae (23 specific, 1 generic, and 5 vegetative groups) were identified in the lotic environments studied in the two drainage basins. Chlorophyta had the highest number of representatives (12 taxa), followed by Cyanobacteria (11), Heterokontophyta (4), and Rhodophyta (2). The proportions of morphological types were: $24 \%$ free filaments (7 taxa), 17,25\% mats, tufts, gelatinous filaments, and gelatinous colonies (5 taxa each), and $7 \%$ crusts ( 2 taxa). All of the taxa, their respective morphological types, and their occurrences at distinct spatial scales are presented in table 2.

Table 1. Average values and standard errors of each of the environmental variables (general and micro-environmental) at different spatial scales in the Pedras river (PRB) and Marrecas river (MRB) basins.

\begin{tabular}{|c|c|c|c|c|c|c|}
\hline \multirow{3}{*}{ Variables } & \multicolumn{6}{|c|}{ Spatial scales } \\
\hline & \multicolumn{2}{|c|}{ Drainage basin } & \multicolumn{2}{|c|}{ Shading } & \multicolumn{2}{|c|}{ Mesohabitat } \\
\hline & PRB & MRB & Open & Shaded & Pools & Riffles \\
\hline Current velocity $\left(\mathrm{m} \mathrm{s}^{-1}\right)$ & $0.220 \pm 0.19$ & $0.260 \pm 0.26$ & $0.23 \pm 0.24$ & $0.22 \pm 0.23$ & $8.14 \pm 2.94$ & $7.87 \pm 2.45$ \\
\hline Depth (cm) & $8.83 \pm 2.61$ & $7.20 \pm 2.52$ & $7.57 \pm 2.62$ & $8.56 \pm 2.67$ & $8.05 \pm 2.89$ & $7.87 \pm 2.45$ \\
\hline Irradiance $\left(\mu \mathrm{mol} \mathrm{m} \mathrm{m}^{-2} \mathrm{~s}^{-1}\right)$ & $382.1 \pm 393.4$ & $326.0 \pm 487.8$ & $644.17 \pm 481.28$ & $73.95 \pm 50.3$ & $383.76 \pm 504.07$ & $324.43 \pm 379.1$ \\
\hline Substrate richness & $1.92 \pm 0.66$ & $1.66 \pm 0.54$ & $1.62 \pm 0.64$ & $1.98 \pm 0.53$ & $1.92 \pm 0.56$ & $1.62 \pm 0.62$ \\
\hline Substrate H' & $0.27 \pm 0.19$ & $0.26 \pm 0.16$ & $0.23 \pm 0.19$ & $0.31 \pm 0.17$ & $0.33 \pm 0.17$ & $0.22 \pm 0.18$ \\
\hline Water temperature $\left({ }^{\circ} \mathrm{C}\right)$ & $12.23 \pm 1.83$ & $15.28 \pm 1.54$ & $13.95 \pm 1.83$ & $13.56 \pm 2.73$ & - & - \\
\hline Oxygen saturation (mg L) & $7.88 \pm 1.26$ & $6.12 \pm 1.12$ & $7.35 \pm 1.24$ & $6.66 \pm 1.66$ & - & - \\
\hline Conductivity $\left(\mu \mathrm{S} \mathrm{cm}^{-1}\right)$ & $35.4 \pm 15.95$ & $34.1 \pm 4.09$ & $32.5 \pm 10.17$ & $37.0 \pm 12.55$ & - & - \\
\hline $\mathrm{pH}$ & $6.36 \pm 0.37$ & $6.95 \pm 0.19$ & $6.6 \pm 0.41$ & $6.71 \pm 0.43$ & - & - \\
\hline Turbidity (NTU) & $4.04 \pm 1.51$ & $4.62 \pm 1.65$ & $4.21 \pm 1.78$ & $4.44 \pm 1.41$ & - & - \\
\hline
\end{tabular}

The following proportions of algal phyla were identified at different spatial scales: Cyanobacteria were encountered in $50 \%$ of the rivers and streams in each drainage basin; in $53 \%$ and $47 \%$ of the shaded and open stream segment respectively; and in $60 \%$ and $40 \%$ of the riffle and pool mesohabitats respectively. Chlorophyta were encountered in $50 \%$ of the rivers and streams in each drainage basin; in $85 \%$ of the open stream segments but only $15 \%$ of the shaded stream segments; and in $60 \%$ of the riffles and $40 \%$ of the pool mesohabitats. The Rhodophyta demonstrated very similar proportions, except at the drainage basin scale, with $67 \%$ of its taxa occurring in the Marrecas river basin and $33 \%$ in the Pedras river basin; with 50\% occurrence in both open and shaded stream segments and in pool and riffle mesohabitats. Heterokontophyta occurred more frequently in the Pedras river basin (67\%); with 50\% occurrence in both shaded and open stream segments, but with greater occurrence $(83 \%)$ in pool rather than riffles mesohabitats (17\%).

The algal morphological types demonstrated very variable proportions, with some very marked distinctions in their occurrences, particularly in relation to the mesohabitats. The proportions of each of the morphological types presented in table 3 considering the percentage of occurrence in the drainage basins (the Pedras and Marrecas river basins), shading regime (open and shaded stream segments), and mesohabitat (pools and riffles).

None of the three DCA axes summarized the taxonomic compositions of the macroalgal communities considering the set of species surveyed. Only the first and second axes are graphically represented here (figure 2) at all of the spatial scales examined. The axes explained very little of the observed variation and none of them could explain the variations in community composition at any of the spatial scales evaluated. The first axis 
Table 2. List of the species present in the lotic environments of the Pedras river and Marrecas river basins. $(\mathrm{P}=$ pools; $\mathrm{R}=$ riffles).

\begin{tabular}{|c|c|c|c|c|c|c|c|c|c|}
\hline \multirow{4}{*}{ Taxon } & \multirow{4}{*}{ Morphological type } & \multicolumn{8}{|c|}{ Occurrence } \\
\hline & & \multicolumn{4}{|c|}{ Pedras river } & \multicolumn{4}{|c|}{ Marrecas river } \\
\hline & & \multicolumn{2}{|c|}{ Open } & \multicolumn{2}{|c|}{ Shaded } & \multicolumn{2}{|c|}{ Open } & \multicolumn{2}{|c|}{ Shaded } \\
\hline & & $\mathrm{P}$ & $\mathrm{R}$ & $\mathrm{P}$ & $\mathrm{R}$ & $\mathrm{P}$ & $\mathrm{R}$ & $\mathrm{P}$ & $\mathrm{R}$ \\
\hline \multicolumn{10}{|l|}{ Cyanobacteria } \\
\hline Blemnothrix komarekii Branco \& Montejano & Mats & & & & $\mathrm{X}$ & & & & \\
\hline $\begin{array}{l}\text { Chroococcopsis fluviatilis (Lagerheim) Komárek } \\
\text { \& Anagnostidis }\end{array}$ & Crusts & & & & $\mathrm{X}$ & & & & \\
\hline Fischerella ambigua (Nägeli) Gomont & Gelatinous colonial & & & & $X$ & & & & \\
\hline Microcoleus subtorulosus Gomont & Mats & & & & $\mathrm{X}$ & & & $\mathrm{X}$ & $\mathrm{X}$ \\
\hline $\begin{array}{l}\text { Nostoc verrucosum Vaucher ex Bornet } \\
\text { \& Flahault }\end{array}$ & Gelatinous colonial & & $\mathrm{X}$ & & & & & & \\
\hline $\begin{array}{l}\text { Nostochopsis lobatus Wood ex Bornet } \\
\text { \& Flahault }\end{array}$ & Gelatinous colonial & & & & & & & $\mathrm{X}$ & $\mathrm{X}$ \\
\hline $\begin{array}{l}\text { Phormidium aerugineo-caeruleum (Gomont) } \\
\text { Anagnostidis \& Komárek }\end{array}$ & Mats & & $X$ & & & $\mathrm{X}$ & $\mathrm{X}$ & & \\
\hline $\begin{array}{l}\text { Phormidium retzii (C. Agardh) Gomont ex } \\
\text { Gomont }\end{array}$ & Mats & $\mathrm{X}$ & $\mathrm{X}$ & $\mathrm{X}$ & $\mathrm{X}$ & $\mathrm{X}$ & $\mathrm{X}$ & $\mathrm{X}$ & $\mathrm{X}$ \\
\hline $\begin{array}{l}\text { Phormidium schroederi (Borge) Anagnostidis } \\
\text { \& Komárek }\end{array}$ & Mats & & & $\mathrm{X}$ & & $\mathrm{X}$ & & & \\
\hline Tolypothrix byssoidea (Hassal) Kirchner & Tufts & & & & & & & & $\mathrm{X}$ \\
\hline $\begin{array}{l}\text { Tolypothrix distorta var. penicillata Kütz ex } \\
\text { Bornet \& Flahalt }\end{array}$ & Tufts & $\mathrm{X}$ & $\mathrm{X}$ & & $\mathrm{X}$ & $\mathrm{X}$ & $\mathrm{X}$ & & \\
\hline \multicolumn{10}{|l|}{ Chlorophyta } \\
\hline Draparnaldia mutabilis (Roth) Bory & Gelatinous filaments & & $\mathrm{X}$ & & & & & & \\
\hline Ecballocystis pulvinata Bohlin var. pulvinata & Crusts & & $X$ & & & & $\mathrm{X}$ & & $\mathrm{X}$ \\
\hline Microspora flocosa Thuret & Free filaments & & $\mathrm{X}$ & $\mathrm{X}$ & & & $\mathrm{X}$ & & \\
\hline Microspora stagnorum (Kützing) Lagerheim & Free filaments & & & & & $\mathrm{X}$ & & & \\
\hline Mougeotia sp. & Free filaments & & $\mathrm{X}$ & & & & & & \\
\hline Oedogonium sp. & Free filaments & & & & & $\mathrm{X}$ & & & \\
\hline Spirogyra sp. & Free filaments & $\mathrm{X}$ & $\mathrm{X}$ & & & & & & \\
\hline Stigeoclonium amoenum Kutzing & Gelatinous filaments & $\mathrm{X}$ & $\mathrm{X}$ & & & & $\mathrm{X}$ & & \\
\hline Stigeoclonium helveticum Vischer & Gelatinous filaments & & & & $\mathrm{X}$ & & & & \\
\hline Tetraspora gelatinosa (Vaucher) Desvaux & Gelatinous colonial & & & & & $\mathrm{X}$ & $\mathrm{X}$ & & \\
\hline Tetraspora lubrica (Roth) C.Agardh & Gelatinous colonial & & & & & $\mathrm{X}$ & & & \\
\hline Zygnema sp. & Free filaments & & & & & $\mathrm{X}$ & & & \\
\hline \multicolumn{10}{|l|}{ Heterokontophyta } \\
\hline Melosira varians C.Agardh & Free filaments & $\mathrm{X}$ & & & & & & & \\
\hline Ulnaria ulna (Nitzsch) Compère & Tufts & & & $\mathrm{X}$ & & & & & \\
\hline Vaucheria sp. & Tufts & $\mathrm{X}$ & & & $\mathrm{X}$ & $\mathrm{X}$ & & & \\
\hline Eunotia sp. & Tufts & & & & & & & $\mathrm{X}$ & \\
\hline \multicolumn{10}{|l|}{ Rhodophyta } \\
\hline $\begin{array}{l}\text { Batrachospermum puiggarianum Grunow in } \\
\text { Wittrock \& Nordstedt }\end{array}$ & Gelatinous filaments & & & & & $\mathrm{X}$ & $\mathrm{X}$ & & \\
\hline Batrachospermum helminthosum Sirodot & Gelatinous filaments & & & $\mathrm{X}$ & $X$ & & $\mathrm{X}$ & $\mathrm{X}$ & \\
\hline
\end{tabular}


Table 3. Proportions of each of the morphological types (percentage of occurrence) in the different spatial scales.

\begin{tabular}{|c|c|c|c|c|c|c|}
\hline \multirow{3}{*}{ Morphological types } & \multicolumn{6}{|c|}{ Spatial scales } \\
\hline & \multicolumn{2}{|c|}{ Drainage basin } & \multicolumn{2}{|c|}{ Shading } & \multicolumn{2}{|c|}{ Mesohabitat } \\
\hline & Pedras river & Marrecas river & Open & Shaded & Pools & Riffles \\
\hline Mats & $48 \%$ & $52 \%$ & $48 \%$ & $52 \%$ & $48 \%$ & $52 \%$ \\
\hline Crusts & $50 \%$ & $50 \%$ & $50 \%$ & $50 \%$ & $0 \%$ & $100 \%$ \\
\hline Gelatinous filaments & $54 \%$ & $46 \%$ & $63 \%$ & $37 \%$ & $37 \%$ & $63 \%$ \\
\hline Gelatinous colonial & $29 \%$ & $71 \%$ & $57 \%$ & $43 \%$ & $43 \%$ & $57 \%$ \\
\hline Tufts & $54 \%$ & $46 \%$ & $54 \%$ & $46 \%$ & $54 \%$ & $46 \%$ \\
\hline Free filaments & $60 \%$ & $40 \%$ & $90 \%$ & $10 \%$ & $60 \%$ & $40 \%$ \\
\hline
\end{tabular}

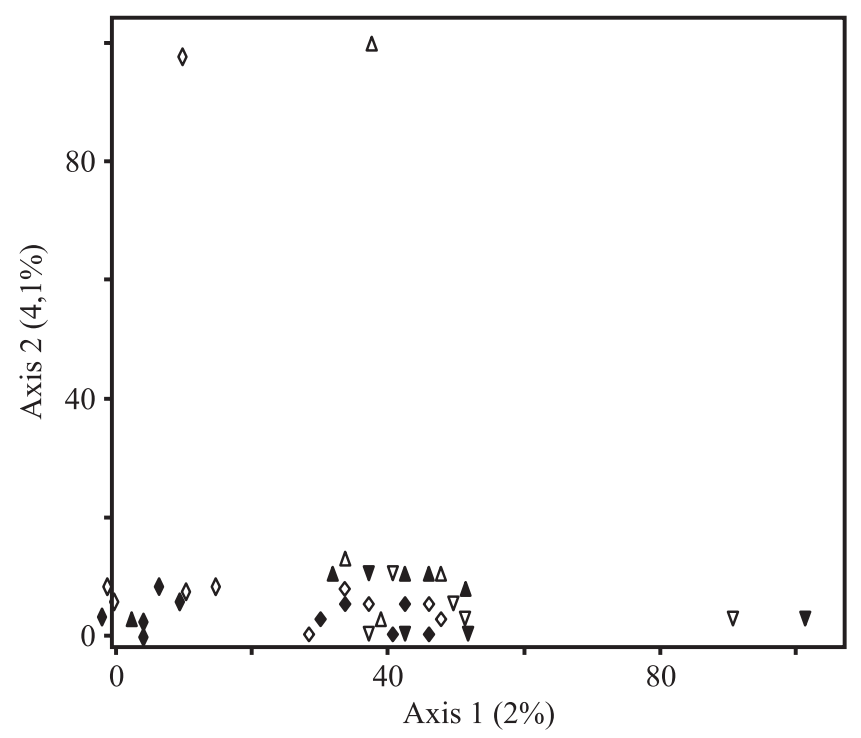

Figure 2. Ordination of the sampling sites by Detrended Correspondence Analysis (DCA). Although axes 1 and 2 are shown, neither demonstrated significant differences in relation to community compositions. $(\triangle=\mathrm{PRB}$, open, riffles; $\nabla=$ PRB, open, pools; $\boldsymbol{\Delta}=$ PRB, shaded, riffles; $\boldsymbol{\nabla}=$ PRB, shaded, pools; $\diamond=\mathrm{MRB}$, open, riffles; $\diamond=\mathrm{MRB}$, open, pools; $\downarrow=\mathrm{MRB}$, shaded, riffles; $\diamond=\mathrm{MRB}$, shaded, pools).

explained only $2 \%$ of the total variance, the second $4 \%$, and the third $19 \%$.

On the other hand, the composition of communities based on algal phyla showed high explicability: $67.7 \%$ ( $1^{\text {st }}$ axis) and $16.7 \%\left(2^{\text {nd }}\right.$ axis $)$ at the scales of the drainage basins and shading, and 50.4\% ( $1^{\text {st }}$ axis) and $35.8 \%$ $\left(2^{\text {nd }}\right.$ axis) at the mesohabitat scale. Distinct ordinations were observed for each of the spatial scales evaluated (figure 3). As such, Rhodophyta were exclusively found in streams of the Marrecas river basin, while Heterokontophyta, Cyanobacteria, and Chlorophyta were common in both drainage basins (figure 3A); at the shading scale, Chlorophyta were best represented in open stream segments, while the Cyanobacteria and Rhodophyta were most commonly observed in shaded stream segments (figure 3B); and at the mesohabitat scale, only Heterokonthophyta species demonstrated an exclusive preference for pools, while the other phyla occurred more or less equally in pools and riffles (figure 3C).

The spatial distribution of sample points with respect to morphological types showed a explicability by axis 1 $(22.8 \%)$ and by axis $2(41.5 \%)$ at the drainage basin and shading scales. Explicability at the mesohabitat scale was $50.3 \%$ for axis 1 and $20.2 \%$ for axis 2 . Separation among spatial scales was less evident for morphological types than for algal phyla (figure 4). In terms of drainage basins, a large proportion of mat were only observed to occur in the Pedras river drainage basin (figure 4A). In terms of shaded regime crusts occurred more frequently in shaded stream segments, while free filaments were found in open stream segments (figure 4B). Among the mesohabitats, free filaments were more common in the pool mesohabitats, while crusts, other filamentous thalli and gelatinous colonies were more commonly observed in the riffles mesohabitat (figure 4C).

\section{DISCUSSION}

Of the total number of species encountered, $65.5 \%$ occurred exclusively in only one of the drainage basins, demonstrating a distinction between the two environments in relation to their species compositions. A few species, however, such as Phormidium retzii, Tolypothrix distorta var. penicillata, and Batrachospermum helminthosum were common in a 

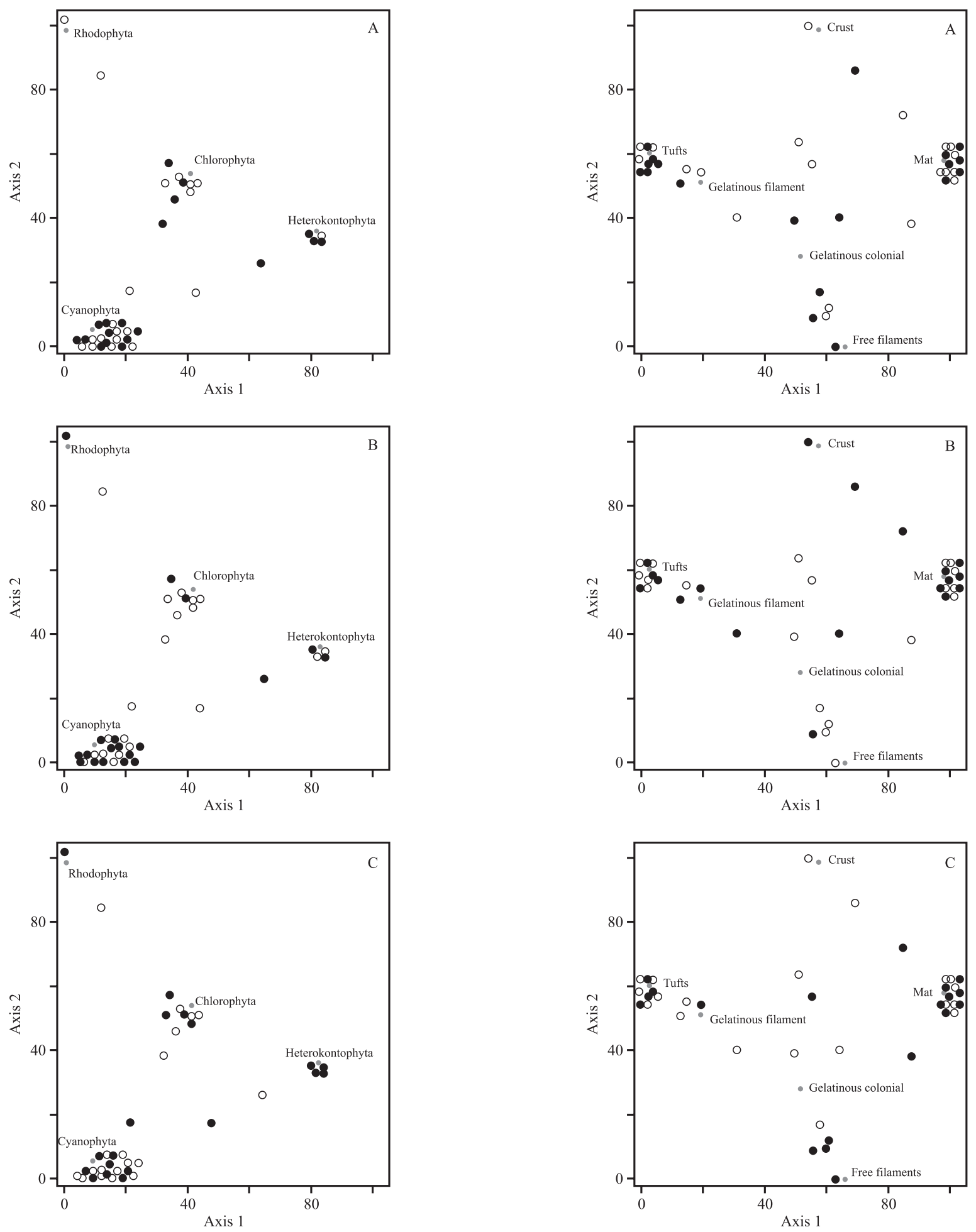

Figure 3. Ordination of the sampling sites by Detrended Correspondence Analysis (DCA) based on the composition of the algal divisions encountered at different spatial scales: A. Drainage basin $(\mathrm{O}=$ Marrecas river basin; $\bullet=$ Pedras river basin); B. Shading $(\mathrm{O}=$ Open environment; $\bullet=$ Shaded environment); C. mesohabitat ( $\mathrm{O}=$ riffles mesohabitat; - = pool mesohabitat) (only the axes with the greatest explained variance [axes 1 and 2] are shown).

Figure 4. Ordination of the sampling sites by Detrended Correspondence Analysis (DCA) based on the composition of the morphological types encountered at different spatial scales: A. Drainage basin $(\mathrm{O}=$ Marrecas river basin; $\bullet=$ Pedras river basin); B. Shading $(\mathrm{O}=$ Open environment; $\bullet=$ Shaded environment); C. Mesohabitat $(\mathrm{O}=$ riffles mesohabitat; $\bullet=$ pool mesohabitat) (only the axes with the greatest explained variance [axes 1 and 2] are shown). 
number of streams in both basins. The occurrence of just a few species in each segment and the reduced total number of species contributed to the overall similarity of the two regions by minimizing the differences in their species compositions (refer to the DCA results). The same situation helps explain the lack of any significant distinctions between the species compositions of the different shading regime and mesohabitats. In terms of shading, $80 \%$ of the species in the Pedras river basin were exclusive to one specific type of shading regime (open or shaded) as were $84.5 \%$ of the species in the Marrecas river basin. A very important characteristic observed in other studies (Krupek et al. 2007) was the high number of species containing phycobilin pigments in their photosynthetic pigment complex in environments with low light levels (because of greater riverside vegetation cover). These pigments apparently provide these algae with a competitive advantage in more effectively using the filtered light spectrum present in shade environments. In the present study, $66.6 \%$ of the species that occurred exclusively in shaded environments were representatives of the Cyanobacteria; while 69.2\% of the species occurring in open environments in the present study were representatives of the Chlorophyta. Green algae have been found to be more abundant and to demonstrate greater species richness in environments with high light availability, while other algal groups mainly Cyanobacteria and Rhodophyta have showed lower species richness and abundances in these kind of environment (Sheath \& Burkholder 1985, Branco \& Necchi Júnior 1996, Peres et al. 2008, Branco et al. 2009).

In considering the different algal phyla, it was clear that representatives of the Chlorophyta lost their competitive advantage in low-light environments where they were almost completely absent in present study. High and constant light availability as observed in open environments is known to generate higher species richness and abundance of green algae (although specimens of other groups can commonly be encountered) (Peres et al. 2008, Branco et al. 2009), demonstrating not only the greater ability of this algal group to develop in environments with high irradiance levels but also their dependence on those conditions (Sheath \& Burkholder 1985, Okada \& Watanabe 2002).

In terms of the mesohabitats, $65 \%$ of the species were exclusive to the pool or riffle in the Pedras river drainage basin and $57.9 \%$ in the Marrecas river basin (refer to the DCA results). The morphological characteristics of each species can be determinant in their occupation of mesohabitats within a stream segment. The majority of the species (66\%) exclusively encountered in pool in the Pedras river basin were free filamentous forms. Wehr $\&$ Sheath (2003) noted that current velocity affected the development of different species and that algae having long, free filaments tended to lose biomass under high water flow. On the other hand, species that occur exclusively in riffles are usually mats $(30 \%)$, crusts (20\%), and gelatinous colonies (20\%) morphological types that are well-adapted to the high current velocities, an evident environmental characteristic of riffle mesohabitats. The same situation was observed in the Marrecas river basin, with $57 \%$ of the free filamentous macroalgal species occurring exclusively in pools, while tufted (50\%) and crust (25\%) species occurred exclusively in riffles.

The similarity values obtained reinforced the above observations, as species composition similarities were never above $41 \%$ at any of the spatial scales evaluated. As such, we observed clear distinctions in species compositions at all of the spatial scales evaluated (principally in terms of environmental shading regime and the mesohabitat) when considering algal phyla and morphological types (refer to the DCA data).

The above mentioned characteristics of the stream macroalgal communities (principally in relation to the low global numbers of taxa encountered and low numbers of species per stream segment) must be taken into consideration when evaluating their structures based exclusively on species composition. According to Grime (1979), community analyses based on the species compositions do not faithfully express the relationships between biotic communities and environmental variablesas each species demonstrates its own combination of characteristics that determine its unique life history. As such, functional types (groups of organisms that demonstrate similar characteristics and therefore respond in similar manners to environmental changes) can be more useful in describing the complexity of those ecosystems (Pillar 1999, Pillar \& Sosinski 2003, Burliga et al. 2004).

A number of studies have shown that local conditions can influence the spatial distributions of macroalgae species in streams (Branco et al. 2009), making it difficult to identify larger patterns for particular species, and those conditions are determined, in turn, by sets of distinct characteristics (e.g., substrate, luminousity and depth) and not by any single factor. Some environmental properties than can directly affect the community as a whole, however, drastically altering both meso- and microhabitats, as is the case of irradiance and current velocity. These variables affect specific areas within 
a stream segment and will favor the development of organisms physiologically and/or morphologically better adapted to occupy those sites. This situation was seen in the present study in the better development of Cyanobacteria in shaded segments and free filamentous algae in pool areas. Therefore, due to the restricted distribution and the low species richness and abundance of lotic macroalgae, we suggested the use of morphological groups associated with taxonomic organization to analyze macroalgal spatial distributions.

Acknowledgments - The authors thank CNPq for the doctoral grant awarded to RAK and for the research scholarship to CCZB (Proc. 302354/2008-5). We also thank Cleto Kaveski Peres for great assistance in the field work.

\section{REFERENCES}

Anagnostidis K, Komárek J. 1988. Modern approach to the classification system of Cyanophytes. 3. Oscillatoriales. Algological Studies 50-53:327-472.

Borges FR, Necchi Júnior O. 2006. Patterns of spatial distribution in macroalgal communities from tropical lotic ecosystems. Revista Brasileira de Botânica 29: 669-680.

Branco CCZ, Krupek RA, Peres CK. 2009. Ecological distribution of stream macroalgal communities from mid-western region of Paraná State. Brazilian Archives of Biological and Technology 52:379-386.

Branco CCZ, Necchi Júnior O. 1998. Microhabitat and morphometric variation of two Chaetophoracean (Chaetophorales, Chlorophyta) species in tropical streams of southeastern Brazil. Phycological Research 46:169-174.

Branco CCZ, Necchi Júnior O. 1996. Distribution of stream macroalgae in the eastern Atlantic rainforest of São Paulo State, southeastern Brazil. Hydrobiologia 333: 139-150.

Burliga ALM, Schwarzbold A, Lobo EA, Pillar VD. 2004. Functional types in epilithon algae communities of the Maquiné river, Rio Grande do Sul, Brazil. Acta Limnologica Brasiliensia 16:369-380.

Gordon ND, Mcmahon TA, Finlaylson BL. 1992. Stream hydrology, an introduction for ecologists. John Wiley \& Sons, Chichester.

Grime JP. 1979. Plant strategies and vegetation process. John Willey \& Sons, Chichester.

Hu BF, Xie SL. 2006. Effect of seasonality on distribution of macroalgae in a stream system (Xin'an Spring) in Shanxi Province, North China. Journal of Integrative Plant Biology 48:889-896.
John DM. 2003. Filamentous and plantlike green algae. In Freshwater algae of North America - ecology and classification (JD Wehr, RG Sheath, eds.). Academic Press, San Diego, p.311-352.

Komárek J, Anagnostidis K. 1986. Modern approach to the classification system of Cyanophytes. 2. Chroococcales. Algological Studies 43:157-226.

Komárek J, Anagnostidis K. 1989. Modern approach to the classification system of Cyanophytes. 4. Nostocales. Algological Studies 56:247-345.

Krebs CJ. 1989. Ecological methodology. Harper \& Row, New York.

Krupek RA, Branco CCZ, Peres CK. 2007. Distribuição ecológica das comunidades de macroalgas da bacia de drenagem do Rio das Pedras, região centro-sul do estado do Paraná, sul do Brasil. Revista Brasileira de Botânica 30:173-182.

Ludwig JA, Reynolds JF. 1988. Statistical ecology: a primer on methods and computing. John Wiley and Sons, New York.

Necchi Júnior O, Branco CCZ, Simões RCG, Branco LHZ. 1995. Distribution of stream macroalgae in northwest region of São Paulo State, southeastern Brazil. Hydrobiologia 299:219-230.

Necchi Júnior O. 1997. Microhabitat and plant structure of Batrachospermum (Batrachospermales, Rhodophyta) populations in four streams of São Paulo State, southeastern Brazil. Phycological Reserch. 45:39-45.

Okada H, Watanabe Y. 2002. Effect of physical factors on the distribution of filamentous green algae in the Tama river. Limnology 3:121-126.

Peres CK, Branco CCZ, Krupek RA. 2008. Macroalgas de riachos da Serra da Prata, leste do Paraná, Sul do Brasil. Acta Botanica Brasilica 22:333-344.

Pillar VD. 1999. On the identification of optimal plant functional types. Journal of Vegetation Science 10:631640.

Pillar VD, Sosonski Junior EE. 2003. An improved method for searching plant functional types by numerical analysis. Journal of Vegetation Science 14:323-332.

Sheath RG, Burkholder J. 1985. Characteristics of softwater stream in Rhode Island. II: Composition and seasonal dynamics of macroalgae communities. Hydrobiologia 128:109-118.

Sheath RG, Cole KM. 1992. Biogeography of stream macroalgae in North American Journal of Phycology 28:448-460.

Van de Hoek C, Mann DG, Jahns HM. 1995. Algae. An introduction to phycology. Cambridge University Press, Cambridge.

Wehr JD, Sheath RG. 2003. Freshwater algae of North America - ecology and classification. Academic Press, San Diego. 